\title{
The Effect of Competence, Professionalism and Experience on Auditor Professional Judgment in Evaluation of Audit Evidence
}

\author{
Muhammad Ishak Amsari, Nurmalasari Rasibo \\ Faculty of Economic and Business, Hasanuddin University, Indonesia \\ a31111307@gmail.com
}

\begin{abstract}
This study aims to determine whether competence, professionalism and experience affect auditor's professional judgment of Supreme Audit Board of Republic of Indonesia in South Sulawesi province in evaluation of audit evidence, either partially or simultaneously. This study used a correlational study design with a questionnaire instrument as a tool for measuring the competence, professionalism and experience variables. The method of analysis was used to test the hypothesis is multiple linear regression, where analysis is based on data from 40 respondents who have completed all the statements and questionnaires. The results of this study indicate that the competence, professionalism and experience simultaneously and partially affect positively the auditor's professional judgment of Supreme Audit Board of Republic of Indonesia in South Sulawesi province in evaluation of audit evidence.
\end{abstract}

Keywords: Competence, professionalism, experience, professional judgment

\section{Introduction \& Literature Review}

Report of the Committee on Basic Auditing Concept of the American Accounting Association define audit as. "A systematic process objectively obtaining and evaluating evidence regarding assertions about economic actions and events to ascertain the degree of correspondence between those assertions and established criteria and communicating the results to interested users". Audit is a function of inspection and supervision to obtain sufficient assurance that the information activities/reports submitted by the agent (manager /government) regarding financial management and assets of the State to the principal (owner /community) has been through a series of evaluation so that can be tested reliability and feasibility. According to UUNo.15 of 2004 on Management and Financial Responsibility State, Article 1 (1) states that the examination is the process of identifying a problem, analysis, and evaluation were conducted in an independent, objective, and professional standards-based inspection, to assess the correctness, accuracy, credibility and reliability of information on the management and financial responsibility of the state. A series of these processes require a judgment to select the information to be processed more effectively and efficiently. Accuracy in auditor judgment will determine the quality of the audit results.

One of the largest state financial audit institutions in Indonesia, namely the Audit Board of the Republic of Indonesia (BPK) in charge of carrying out checks on the financial state and local finance through the audit function. The audit function is expected to be an extension of the hands and eyes of the public to assess the specific competencies of each action and the report submitted by the manager (government /management). More specifically in governmental auditing the audit function could be very instrumental in the realization of good governance, transparency, and responsibility or commonly called a good and clean governance, in accordance with its vision of "Becoming audit institution financial free, independent, and professional as well as play an active role in realizing the country's financial governance accountable and transparent". UU No. 15 2006, Article 6 paragraph (1) of the BPK stated that the BPK in charge of examining the management and accountability of state finances conducted by the Central Government, Local Government, State Institutions other, Bank Indonesia (BI), Enterprise State Owned Enterprises (BUMN), the Public Service Agency (BLU), Regional-Owned Enterprises (enterprises), as well as institutions or other entities that manage state finances. In Article 7 paragraph (1) and (2), explained that the results of the investigation will be used by the users of financial information state / local House of Representatives (DPR), the Regional Representatives Council (DPD), and the Regional Representatives Council (DPRD) to follow up in accordance with the disciplinary rules of each institution representative. Audit covers all elements of the state finance as stipulated in UU No. 17 of 2003 Article 2 on State Finance include Budget (APBN), Budget (APBD), State-Owned Enterprises (SOEs), Regional-Owned Enterprises (enterprises) and a wealth of other parties that obtained using government facilities. This thing shows the large number of users of reliable audit information for Indonesia's government development. 
Dr. Rizal Djalil as chairman of the BPK in his book "qualitative considerations: New Approach to Auditing" (2014) explains that the opinion given by the BPK on the financial statements of the central government/area becomes a topic much discussed in recent years. Critics of the unqualified opinion (WTP) given by the BPK does not reflect the real condition of a government entity that is involved in corruption cases. An example is the provision of WTP opinion of the Ministry of Religious Affairs when there are cases of corruption in the procurement of the Koran, Hambalang case, and SKKMigas. According to Rizal such cases are a gap between public expectations by giving opinions by the BPK. Decisions about the amount and type of evidence collected anything that requires professional judgment of an auditor. During the assignment of the audit an auditor must use professional judgment in evaluating audit evidence, determine the estimated size of the sample and decide among the options available (Arens et al., 2009: 173) Therefore, the examination of audit evidence required a judgment appropriate to the things that material. When examining evidence of an auditor should assess the circumstances surrounding the occurrence intensity a transaction account, span of control and how many stakeholders involved. An auditor in carrying out its duties should choose whatever evidence you need more in-depth examination in an audit of financial statements. This was caused by considerations of time, the auditor does not examine all parts of the population object to be examined but take samples. This suggests that the judgment of auditors to audit evidence becomes very important, transactions or accounts that have a higher risk will have a higher level of materiality. Judgment auditor in gathering evidence and objective evaluation of the adequacy, competence and relevance of evidence will certainly determine the quality of opinions will be issued. Hutabarat (2012) found the quality of his judgment related auditors strongly influenced opinions. It is based on the perspectives, knowledge, and experience in certain situations and conditions.

Boynton et al. (2001: 206) that the good condition of the audit evidence is the evidence must be sufficient and competent so that it can be an adequate basis in the formulation of the audit findings. Evidence is said to be enough when the quantity has been qualified to support confidence in the validity and reliability of audit findings. Evidence is said to become patent when the evidence is relevant, timely, objective, and is derived from a competent source. Arens et al. (2009: 174) argues that in determining how an audit evidence is said to be quite competent, yet there is a standard that can be used as a reference and guidelines so that the necessary professional judgment (professional judgment) auditors in its determination. Law No.15 in 2016 on the Audit Board of the Republic of Indonesia Article 1 explains that the Inspection Standards are the benchmark for examination management and financial responsibility of the state which includes general standards, standard implementation of the inspection and reporting standards that must be guided by the CPC and/or examiner. Boynton et al. (2001: 60) explains that common standard audit standards related to audit or qualifications and quality of work of auditors, field work standard is a standard relating to the audit client place. Meanwhile, the reporting standard is the standard that must be meting reporting the results of the audit/report the results of the audit.

Therefore, auditors in performing their duties especially in making judgment must have expertise and specific training especially as auditors working in the public sector are responsible for providing information to the public. Competencies/skills of an auditor greatly affect his judgment, because it is a subjective thing of an auditor and will certainly affect the quality of the audit reports produced. According Maulidah (2014) professionalism is a key issue today for auditors, external auditors in particular, because there are many cases due to irregularities in terms of professionalism. High professionalism may indicate that an auditor can be trusted because freedom is assured from various external parties so that the auditor can give their opinions in accordance with the actual condition. The level of professionalism of auditors can be seen through how an auditor upholding the basic values of the profession. Agusti and Earth (2013) describes in his research that professionalism has five important factor inside the dedication, social obligations, self-reliance, confidence in the regulatory profession and relationships with colleagues.

In addition to the competence and professionalism, an auditor must also have sufficient experience so as to make the decision (judgment) in audit reports. As has been explained previously that the auditor's consideration on matters which are material professional judgment and influenced the perception of the auditor. "Auditors who have different experiences will be different in looking at and responding to information obtained during the examination and also in providing audit conclusions of the object being examined for the provision of opinions"(Friska, 2012). With a wealth of experience in auditing financial 
statements the auditor's consideration of materiality levels will be more accurate. Mulyadi (2012: 89) states that" in carrying out its audit work, the auditors often encounter situations that involve risks irregularities so that the auditor must always be vigilant when faced with a situation containing a high risk audits that contains the presentation particularly wrong material misstatement". Irregular situation like this cannot be interpreted easily just by reading a book or certain theories and therefore with much experience will be easy to train auditors skeptical capabilities. The experience will certainly add a lot of knowledge in considering the materiality level so that a more accurate evidence audit annyapun report will be qualified and able to provide reasonable assurance for the users of the report.

Basically this study is a replication of the study by Amaliana (2014), which examines the influence of experience and competence of the auditor's professional judgment in the evaluation of evidence in the BPK. Amaliana (2014) found empirical evidence that the experience and competence of auditor's factors affect the auditor's professional judgment in evaluating the evidence. Differences in this study with research of Amaliana (2014) are that in this study there is a new variable that is professionalism. It is based on the opinions Irawan (2011) that the auditor's judgment is a subjective thing so high professionalism of an auditor is required to produce a quality audit results and neutral. In addition, respondent's research is the government's external auditor BPKRI Representative of South Sulawesi province. Based on the above explanation the researchers intend to conduct research with the title "The Effect of Competence, professionalism, and experience the Auditor Professional Judgment in Evaluating Audit Evidence (Empirical Study on the Office of Audit Board RI Representatives of South Sulawesi province)"

\section{Methodology}

Research Objectives: The design of this study was correlational studies (correlational study) that studies used to be able to see whether or not the relationship between the variables studied and can find which are the most dominant variable related to the problems examined (Sekaran, 2009: 165). The purpose of this study is to test the hypothesis (hypotheses testing), which is expressed in the form of statements and explain the relationship that can be predicted logically between two or more variables so that a solution can be found to overcome the problems encountered (Sekaran, 2009: 135). This study uses data obtained from the primary data source that questionnaires filled out by the respondents that the auditor BPK RI Representative of South Sulawesi province.

\section{Problem Statements}

- Is the competence factor affect auditor professional judgment in BPK RI Representative of South Sulawesi province in Evaluating Audit Evidence?

- Is the professionalism factor affect auditor professional judgment in BPK RI Representative of South Sulawesi province in Evaluating Audit Evidence?

- Is the experience factor affect auditor professional judgment in BPK RI Representative of South Sulawesi province in Evaluating Audit Evidence?

- Are the competence, professionalism, and experience factors simultaneously affecting auditor professional judgment in BPK RI Representative of South Sulawesi province in Evaluating Audit Evidence?

\section{Hypothesis}

H1: Competence partially affect positive to Auditor Professional Judgment BPK RI Representative of South Sulawesi province in Evaluating Audit Evidence.

H2: Professionalism partially affect positive to Auditor Professional Judgment BPK RI Representative of South Sulawesi province in Evaluating Audit Evidence.

H3: Experience partially affect positive to Auditor Professional Judgment BPK RI Representative of South Sulawesi province in Evaluating Audit Evidence.

H4: Competence, professionalism, and experience simultaneously affect the Professional Judgment Auditor BPK RI Representative of South Sulawesi province in Evaluating Audit Evidence.

Data Collection: Data collected through the questionnaire method is by giving a list of questions (questionnaire), which have been compiled in a structured and refers to the study variables, it is intended to 
gather information or data that will be used to analyze the problem. Questionnaires were sent directly to the institution that became the object of research. Number of questionnaires provided investigators corresponds to the number of samples that is at least thirty copies. The object of this study is the auditor of BPK RI Representative of South Sulawesi province. The data used in the primary data by distributing questionnaires to Auditor of BPK RI Representative of South Sulawesi as many as 55 copies. Questionnaires are distributed directly to the office of BPK RI Representative of South Sulawesi Province through a sub-section of Human Resources. Questionnaires were returned by 40 auditors, while 15 were not returned.

Table 1: Summary of Response Rate

\begin{tabular}{ll}
\hline Total Questionnaires & 55 \\
Returned Questionnaires & 40 \\
Non-Returned Questionnaires & 15 \\
Response Rate & $73 \%$ \\
\hline
\end{tabular}

Sample Data Analysis: In this study, respondents were asked to answer the questionnaire consisted of three part. The first part, consisting of a questionnaire data contains general data and the identity of respondents. The second part, relating to the variables included in the component auditor's professional judgment BPK RI Representative of South Sulawesi province in evaluating audit evidence. In this section consists of questions representing each independent variable competence, professionalism, and experience. The third part of the questionnaire contains questions-pertnyaan related to the professional judgment of auditors of BPK RI Representative of South Sulawesi province in evaluating audit evidence. Descriptive statistics were used to describe each group which consist of either or combination of frequency, percentage, mean and standard deviation of related answers for forensic accounting. Methods of data analysis used in this study are multiple linear regression analysis. This analysis is intended to reveal the influence of several independent variables with the dependent variable. Methods of data analysis used in this study are the method of statistical analysis using SPSS 20.0.

\section{Results and Discussion}

Descriptive statistics in this study use to describe the state of the demographic characteristics of respondents. Demographics of respondents classified by age, sex, education last, long work and the division of the entity (Sub-Auditorate).

Table 2: Demographic Profile and Respondents

\begin{tabular}{lll}
\hline Descriptions & $\begin{array}{l}\text { Total Respondents } \\
\text { (person) }\end{array}$ & $\begin{array}{l}\text { Percentage } \\
\text { (\%) }\end{array}$ \\
\hline Age & 7 & 17 \\
a. Unknown & 15 & 37 \\
b. 20-30 years & 12 & 30 \\
c. 31-40 years & 6 & 15 \\
d. $>40$ years & & \\
Sex & 0 & 0 \\
a. Unknown & 20 & 50 \\
b. Man & 20 & 50 \\
c. Female & & \\
Last Education & 8 & 20 \\
a. Unknown & 20 & 50 \\
b. S1 & & \\
c. S2 & 12 & 30 \\
c. S2 & & \\
\hline
\end{tabular}


d. S3

Length of Work

a. Unknown

b. $0-5$ years

c. $5-10$ years

d. $>10$ years

Division of Regional Entities (Sub-

Auditorat)

a. Unknown

b. Sulawesi Selatan I

c. Sulawesi Selatan II

d. Sulawesi Selatan III
0

6

7

20

7
0

15

17

50

17

Descriptive Statistics: To give an idea of the study variables (competence, professionalism, experience, and professional judgment); researchers used a descriptive statistical tables. From the table, based on answers from 40 respondents, the results of measurements of professional judgment variable (Y) obtained answer score average (mean) 37.73 with a standard deviation of 4,368. The results of the measurement of competence variable (X1) obtained a score of respondents had an average of 30.50 with a standard deviation of 2,207. The measurement results professionalism variables (X2) obtained an average score of answers 33.30 with a standard deviation of 3,488 . The measurement results of experience variable (X3) obtained an average score of answers 33.92 with a standard deviation of 3.277 .

Table 3: Descriptive Statistics

\begin{tabular}{llllll}
\hline & N & Minimum & Maximum & Mean & Std. Deviation \\
\hline Competence & 40 & 24 & 35 & 30,50 & 2,207 \\
Professionalism & 40 & 25 & 40 & 33,30 & 3,488 \\
Experience & 40 & 26 & 40 & 33,92 & 3,277 \\
Professional Judgment & 40 & 26 & 45 & 37,73 & 4,368 \\
Valid N (listwise) & 40 & & & & \\
\hline
\end{tabular}

Multiple Linear Regression Analysis: Based on the model output display summary in the table below the amount of R Square (coefficient as adjusted) was 0.925 , this value indicates that $92.5 \%$ of variation judgment external auditors of the government in this case the auditor of BPK RI Representative of South Sulawesi province can be explained by a third independent variables are competence (X1), professionalism (X2) and experience (X3), while the remaining $7.5 \%$ is explained by other factors outside the model.

Table 4: Model Summaryb

\begin{tabular}{lllll}
\hline Model & R & R Square & $\begin{array}{l}\text { Adjusted } \\
\text { Square }\end{array}$ & RStd. Error of the Estimate \\
\hline 1 &, $962^{\text {a }}$ &, 925 &, 918 & 1,249 \\
\hline
\end{tabular}

a. Predictors: (Constant), Pengalaman, Kompetensi, Profesionalisme

Partial Testing (t Test): $t$ tests were used to examine individually the relationship between the independent variable (variable X) and the dependent variable (variable Y) (Sugiyono, 2013: 235). The ttest is done by paying attention to the significance of the $t$ value on the output calculation with alpha level of $5 \%$. If the value of the $t$ test of significance is less than $5 \%(<0.05)$, then there is the influence of the independent variables on the dependent variable individually (partial). In this study, the $t$ test was used to test whether the hypothesis proposed in this study received or not to determine whether the individual independent variables affect the dependent variable. The method in the determination of $t$ table using the provisions of the $5 \%$ significance 
level with $\mathrm{df}=\mathrm{n}-\mathrm{k}-1$ (in this study $\mathrm{df}=40-3-1=36$ ), in order to get the value $t$ table of 1.688 . The test results $\mathrm{t}$ test on this study can be seen in the table below:

Table 5: Coefficients ${ }^{a}$

\begin{tabular}{lllllll}
\hline Model & & \multicolumn{2}{l}{$\begin{array}{l}\text { Unstandardized } \\
\text { Coefficients }\end{array}$} & $\begin{array}{l}\text { Standardized } \\
\text { Coefficients } \\
\text { Beta }\end{array}$ & t & Sig. \\
\hline \multirow{4}{*}{1} & (Constant) & $-10,407$ & 2,891 & & $-3,600$ &, 001 \\
& Competence &, 477 &, 196 &, 241 & 2,429 &, 020 \\
& Professionalism &, 601 &, 113 &, 480 & 5,323 &, 000 \\
& Experience &, 400 &, 116 &, 300 & 3,435 &, 002 \\
\hline
\end{tabular}

Simultaneous Significance Testing ( F Test): Testing the hypothesis to seek simultaneous effect of independent variables on the dependent variable was analyzed using the F test, namely by paying attention to the significance of the $\mathrm{F}$ value at the output calculations with an alpha level of $5 \%$. F-test was conducted to prove the fourth hypothesis (H4) the competence; professionalism and experience simultaneously affect the auditor's professional judgment BPK RI Representative of South Sulawesi province. If the value of F tests of significance less than $5 \%$, then there is the influence of all independent variables on the dependent variable. The test results of $\mathrm{F}$ test in this study can be seen in the table below:

Table 5: ANOVA ${ }^{\mathrm{a}}$

\begin{tabular}{lllclll}
\hline Model & & $\begin{array}{l}\text { Sum } \\
\text { Squares }\end{array}$ & ofdf & $\begin{array}{l}\text { Mean } \\
\text { Square }\end{array}$ & $\boldsymbol{F}$ & Sig. \\
\hline \multirow{2}{*}{1} & Regression & 687,849 & 3 & 229,283 & 147,065 &, $000^{\mathrm{b}}$ \\
& Residual & 56,126 & 36 & 1,559 & & \\
\hline & Total & 743,975 & 39 & & & \\
\hline
\end{tabular}

\section{Conclusion}

Based on the analysis of data and discussion can be concluded as follows:

- Competence positively effect on the auditor's professional judgment BPK RI Representative of South Sulawesi province in evaluating audit evidence.

- Professionalism positively effect on the auditor's professional judgment BPK RI Representative of South Sulawesi province in evaluating audit evidence.

- Experience positively affects the auditor's professional judgment BPK RI Representative of South Sulawesi province in evaluating audit evidence.

- Competence, professionalism, and experience auditor simultaneously affect the auditor's professional judgment BPK RI Representative of South Sulawesi province in evaluating audit evidence.

Limitations and Suggestions: Researchers realized that there are still many limitations during the course of the research. The limitation of the possibility of providing interference in the results. This study uses a questionnaire instrument. The use of the questionnaire can cause response bias of the respondents as a result of dishonesty or respondent is not serious in answering the questions. In addition, the use of a questionnaire instrument is certainly not able to describe what happens to objects of research as a whole. Less number of respondents who obtained it certainly reduces the degree of representation for another auditor who is not a respondent. Thus, this research has not represented the perception of auditor BPK RI Representative of South Sulawesi Province evenly in every region of the entities, but only represents the perception of auditor generalization as a unified work. The results of this study cannot be digenaralisasi to all auditors in BPK RI in Indonesia because the scope of this study focuses only on the auditor BPK RI Representative of South Sulawesi province. Several limitations of the study above needs some repair items so the researchers next had a relationship with the object of this study can provide better research results. Some suggestions that, in association with observations directly to the object of research to avoid response bias due to the use of 
questionnaires. The addition of the sample as well as the study population will be able to maximize the representation of the overall perception of the auditor. The addition of some other variables used in measuring the factors that affect the auditor's professional judgment is also recommended.

\section{References}

Agusti, R. \& Putri, N. (2013). Pengaruh Kompetensi, Independensi Dan Profesionalisme Terhadap Kualitas Audit. Jurnal Ekonomi, 21(3). Jurusan Akuntansi Fakultas Ekonomi Universitas Riau.

Amaliana, H. (2014). Pengaruh Pengalaman dan Kompetensi terhadap Penggunaan Professional Judgment auditor dalam Evaluasi Bukti Audit. Surakarta: Fakultas Ekonomi dan Bisnis Universitas Sebelas Maret.

Arens, A., Alvin, E., Randal, J. \& Beasley, S. M. (2009). Auditing and Assurance Services. Twelve Editions. New Jersey: Pearson.

Ariyanto, D. (2010). Pengaruh Independensi, Kompetensi, dan Sensitivitas Etika Profesi terhadap Produktivitas Kerja Auditor Eksternal.

Boynton, W. G., Kell, P. \& Johnson, R. N. (2001). Modern Auditing. Seventh Edition. Terjemahan oleh Paul A. Rajoe, Gina Gania dan Ichsan Setiyo Budi.Edisi Ketujuh Jilid I. 2002. Jakarta: Erlangga.

Djalil, R. (2014). Pertimbangan Kualitatif : Pendekatan Baru dalam Audit. Jakarta: RMBOOKS

Friska, N. (2012). Pengaruh Profesionalisme Auditor, Etika Profesi dan Pengalaman Auditor Terhadap Pertimbangan Tingkat Materialitas. Skripsi dipublikasikan. Yogyakarta: Fakultas Ekonomi Universitas Negeri Yogyakarta.

Hutabarat, G. (2012). Pengaruh Pengalaman Time Budget Pressure dan Etika Auditor terhadap Kualitas Audit. Jurnal Ilmiah ESAI, 6(1).

Irawan. (2011). The Design of Spencer Generic Competency as A Model for Banking Supervisors Position Specification in Surabaya. Journal of Economics, Business and Accountancy Ventura, 14(3).

Mulyadi. (2002). Auditing. Jakarta: Salemba Empat

Maulidah, D. (2014). Pengaruh Penerapan Corporate Governance terhadap Earnings Management dalam Perusahaan Perbankan di Indonesia. Ejournal Unesa Jurnal Akuntansi, 2(3).

Peraturan Badan Pemeriksa Keuangan Republik Indonesia, Nomor 01 Tahun 2007 tentang Standar Pemeriksaan Keuangan Negara.

Peraturan Badan Pemeriksa Keuangan Republik Indonesia, Nomor 02 Tahun 2007 tentang Kode Etik BPK RI.

Sekaran, U. (2009). Research Methods for Business. Terjamahan Oleh Kwan Men Yon, 2010.Jakarta: Salemba Empat.

Sugiyono. (2013). Statistika Untuk Penelitian. Bandung: Alfabeta.

Tim Penyusun Pedoman Penulisan Skripsi. (2012). Pedoman Penulisan Skripsi. Makassar: Fakultas Ekonomi dan Bisnis Universitas Hasanuddin. 